\title{
Bone Fractures as Viewed by Ibn Sīnà
}

\author{
AN Kaadan, $M D, P h D$ \\ Aleppo, Syria
}

\begin{abstract}
Ibn Sinä, or Avicenna as known in the West, was a well known Islamic philosopher and physician. He composed 276 works, the most famous of which is "al-Q anun fit-Tibb." This paper highlights the bone fractures that may occır, described in Ibn Sina's "al-Qānūn," and reveals his accomplishments and contributions to this field of medicine.
\end{abstract}

Kcy words: Ibn Sìnā, Avicenna, Al-Qänün fit-Tibb, History of Traumatology.

DOI: http://dx.doi.org/10.5915/27-4-14428

bo Sinä. or Avicenna as known in the West, was born in 980 A.D. in Afshama near Bukhārä in Turkistan, which is now Uzbekistan. He lef Bukhārā when he was 21 years old to spend the rest of lis life in various Persian lowns. Ibn Sina

From she Instiute for the History of Arabic Sciences

Aleppo University

Aleppo, Syria

Reprint Requests: A. N. Kaadan, M.D., Ph.D. Institule for the History of Arabic Siciences

Aleppo Universily

P.O. Box 7581

Aleppo, Syria composed 276 works, all written in Arabic except a few small books written in his mother tongue, Persian. "Al-Qänūn fit-Tibb," which is written in Arabic, represents Ibn Sina's most important work. Osler described it as the most famous medical textbook ever written.'

Ibn Sina devoted two treatises in the fourth book of his medical encyclopedia, "al-Qänun," to fractures. The first treatise is entitled: "Fractures as a Whole," and the second is "Fractures of Every Bone Separately."

In the first treatise, he described the causes, types, forms, methods of treatment, and complications of fractures. While in the second treatise, he determined the special characteristics of fractures of each bone. Ibn Sina, by this way of explanations, was very close to following the format of modern medical textbooks. 


\section{The first treatise - Fraclures as a Whole}

Ibn-Sina defined a fracture as a loss of continuation in the bone. ${ }^{2}$ Then, he determined the types of fractures such as transverse, longitudinal, or comminuted. When he talked about symptoms and signs of a fracture, he considered the pain, swelling, and deformity of the limb to be of great importance to the diagnosis.

In this chapter, Ibn-Sina distinguishes the fractures that reach the joint line. "If the fracture was at the joint line and healed, the novement of the joint could be difficult as the rigidity of the callus needs more time to become soft,"' he said. It is well known now that fraclures that occupy the joint line cause stifness of that joint after they heal, unless convenient physiotherapy is applied to the limb.

\section{Factors that stimulate and inhibit bone healing}

Ibn Sina mentions that fraccures of children heal more rapidly than those of adults. He determined the time span necessary for every bone to heal.

He said, for example, a nose bone fracture needs 10 days 10 heal, a rib needs 20 days, a forearm needs 30 to 40 days, and a femur need 50 10 120 days. It is a clear that these figures are similar to those written in modern medical texibooks

At the end of this chapter, he pointed out the factors that affect negatively bone healing, such as the lack of a splint at the site of the fracture, quickness in noving the affected limb. loss or blood (aneınia), and the existence of a disease in the body. These factors, and others, are now considered to have a considerable role in delaying bone healing.

\section{Principles of splining the bone}

In this chapter, Ibn-Sinä talked about treating a bone fracture by splinting it. He warned the physician against overtighening the affected limb, which could cause gangrene.

In respect to what is alled now open fracture, he pointed out the importance of taking care of the wound more than the fracture. If the fracture was complicated by hematoma formation, Ion Sina advises the bone setter to make an incision at the sile of swelling to allow the blood to get out.

In this chapter, Ibu Sina also focuses on a very imporlant issue in the treatnent of comminuted fractures. He said: if the fracture is associated with a sequestrate and is painful. it las to be mended and reduced into its position. If this is impossible, the sequestrum has to be excised using a thin saw or by drilling many holes at the base. Whatever the melhod. the doctor has to be very careful not to injure an important structure. Sometimes the sequestrum is not visible; its position can be identified by remarking the discharge from the wound. In such cases, the wound must be enlarged to allow the removal of the sequestrum.s

\section{Recommendations to the bone setter}

Before trealing any frnclure, lbu Sina advised, the plyy- sician should inspect and examinc the fraclure accurately and splint it quickly because fracture reduction will be more difficult and complications may develop if there is a delay.

At the same time, Ibn Sina drew altention to the necessity of not splinting the fracture immediately. He advised postponing it beyond the fifth day or more, until the swelling disappeared. This is called now the theory of delayed splintage, and professor George Perkins is considered the pioneer of this theory today. ${ }^{6}$

\section{Fractures associated with a wound (open fraclures)}

In this chapter, Ibn Sina talked about treating fractures associated with a wound. He stressed the necessity of not applying a splint to the wound; ointment should be put on first, then the wound may be covered by a special dressing that would let out the wound discharge, and allow the physician to apply medicine.

This method of treating open fractures as described by Ibn-Sina is similar, in many aspects, to that used today, except the use of antiseptic procedures during the course of treatment.

\section{Malunion fractures}

What lbn Sina meant by malunion fracture was a fracture that is joined in a nonsuitable position, allowing the limb to become deformed. To treat this case, he suggested breaking the bone again at the site of old fracture and splinting it properly. If the callus is hard. this method should be avoided, otherwise a fracture may occur elsewliere. In such cases. Ibn Sina advised the bone setter 10 apply material that softens the callus until the limb can be splinted in the correct position.

Today, all types of malunion are treated surgically.

\section{The second treatise - Fractures of every bone separately Skull fractures}

Ibn Sina clarified that a skull fracture may happen even if the skin above it is still intact. In sucls cases, a bemaloma may develop under the skin. The physician should nol omil fracture treatment because this may lead to bone decay. The patient may complain of tremors and mind loss. In such cases, Ibn Sina advised the operator to make an incision at the site of fracture to treat it. Next, he described the signs of skull fracture such as unconsciousness. dizziness, and speech loss.

At the end of this chapter, Ibu Sina said. "If the fracture is severely comminuted it should be completely excised. but if it is linear and distended you slould nol widen the incision, as no damage could result from llie fracture."7

\section{Mandible fractures}

The method Ibn Sina describes for treating these fractures resembles what is used today, except in some modern special surgical techniques. In this respect, he said that if the fracture is in the right side and displaced internatly, the 
physician must insert his left index and middle fingers into the patient's mouth to elevate the Gracture cdge oulward. The complete reduction could be identified by a good occlusion of teeth.

If the fracture is comminuted or associated with a wound. Ibn Sina said to make an incision at the fracture sife, and remove any sequestrum that may be present. He advises the physician to suture the teeth using a gold wire in order to stabilize the correct position of the mandible. The patient is asked to remain at rest and avoid speaking. His diet should be liquids. The mandibular bone needs three weeks to heal; it is filled with bone marrow.

\section{Nose-bone fraciures}

Ion Sina stated that a delay in treating a nose-bone fracture may lead to tilting of this bone, and anosmia may develop. So, he insisted on treating this fracture during the first 10 days. If the fracture is comminuted, and the reduction is impossible, the bone setter should incise the skin and remove all the comminuted bone.

\section{Clavicle fraclures}

Ion Sina's treatmell of clavicle fractures is extremely different from those known today. he considered clavicle fractures difficult to splint. He described a long method to achieve a complete reducsion. Today, this fracture is considered easy to treal, and complete reduction is not required 10 achieve healing.

\section{Shoulder fractures (fracture of scapula)}

Ion Sina said: "The shoulder is rarely fractured in its broadest part, but its borders and sides are commonly affccled. ... The most common signs are pain and crepitation on palpation. and the patient may complain of anesthesia in the hand . . . . This fracture is treated by pushing the shoulder from the anterior aspect as a trial to reduce it; otherwise, the physician has to use cupping glasses in order to iracl the fraclured part posteriorly.... In cases of existence of some painful bone fragments, they should be excised .... After the treatment the patient is asked to sleep on the intact side."

All types of scapular fractures need no more treatment than rest until the pain subsides.

\section{Fractures of the slcrnum}

lbn Sina classificd this fracture into types;

1. an isolated splitling fraclure, which is diagnosed by the existence of crepitation on palpation and

2. a fracture that is displaced anteriorly and may cause bad symptoms sucly as difficulty in breathing, dry cough, and, sometimes, hemoptysis.

The treatment of this fracture is similar to that of the shoulder

Rib fractmes
In this chapter, Ibn Sina stated that the seven true ribs are fractured at their lateral sides, while the false ribs are fractured at their medial sides. The diagnosis of a rib fracture is very easy to determine by palpation, which allows the physician to feel abnormal movement at the fracture site. The patient may complain of pleurisy and hemoptysis. The treatment is accomplished by using cupping glassing to tract the fractured rib. If the bone is compressing the diaphragm, the skin must be incised to excise carefully that bone.

\section{Veriebral fractures}

Ibn Sina talked about vertebral fractures very briefly, perhaps because of the rarity of information about these fractures at that time. He attributed all this information to Paulus Egine (who is a famous surgeon from the Alexandria school who lived in the 7th century and wrote a medical book containing seven treatises in surgery and obstetrics, translated into Arabic by Hunin Ibn Ishā (i) ${ }^{\circ}$

Ibn Sina drew the physician's attention to the danger of this type of fracture that could cause death if the cervical vertebrae were involved.

Finally, he described the method for reducing coccygea? fractures by inserting the left index finger into the patient's rectum.

\section{Humeral fractures}

Ibn Sina elucidated that this fracture often tilts outside, so the physician must reduce it according to this tilting. It should be stabilized by using three bandages; the first one is ascending while the second is descending and the third is ascending. The upper limb must be stabilized in an angular shape with a sling. It is better to stabilize it to the chest to prevent movement.

After seven to 10 days, the bandages should be released and replaced by applying suitable splints for another 40 days.

\section{Forearm fractures}

Ibn Sina said: "Both of ulnas or one of them may be fractured. The fracture of the inferior one is more bad, while the fracture of the superior one is more easy to treat." 10 A1 that time, the bones of the forearm were called the superior ulna (radius) and the inferior ulna (ulna).

Ibn Sina explained the method for stabilizing the fractured forearm. He said not to tighten the bandage too much. otherwise severe swelling of the fingers may develop, and not to loosen it, so no swelling at all may appear. After that, he explained a very important item that still occupies a considerable role in the field of treatment of forearm fractures: the necessity of not applying the splints so they extend beyond the base of the fingers, which may cause these fingers to become stiff.

After accurate reduction and complete stabilization are achieved, Ibn Sina advised the physician to sling the af- 
fected forearm to the nock in an angular slape by using a wide rag so that it covers the whole length of the forearm. Forearm fractures heal quickly (within 28 days).

\section{Wrist fraciures}

Ibn Sina said: "These boncs rarely fracture, as they are very hard. And if they are severely injured, dislocation may result, which could be treated as we had said in the dislocalions section." "I

It is well known loday that wrist fractures are extremely rare, except for scaphoid fractures, which cannot be diagnosed without performing an $X$-ray on the wrist joint.

\section{Finger bone fractures}

In this chapter. Ibn Sina said that finger bones are affecled more by dislocations than by fractures. To treat finger fractures, the patient is seated on a high chair and is told to put his hand on a flat chair, an assistant extends the fracture bones, and the physician reduced them with his Ulumb and index fingers.

Ion Sina pointed to what is called now "Bennet's fraclure 1982"12 when he said, "If the fracture was in the thumb and was displaced inferiorly, then you have to use the broad baridage from above 10 prevent the occurrence of the host tumor."

Ibn Sina said if the fracture is in the thumb, it should be bound to the hand; if it is in the index or small finger, it should be binded to the nearest finger.

\section{Broad bone and hip fractures}

This chapter represents the cases of central hip fracture-dislocation and fracture of the sacrum, which was called the broad bone at that time.

Ibn Sinà said a central hip fracture-dislocation rarely occurs. The injured patient may complain of severe pain and anesthesia in his leg and thigh, resembling that of an arm or shoulder fracture.

In order 10 achieve a good reduction in broad bone fraclures, he sajd the physician should put the patient in a prone position, and two strong people should tract the patient's two thighs while two people use splints to try to reduce the fracturc and put on the bandages.

\section{Femur fraclures}

Ibn Sina said: "If the femur fracture needs severe traction 10 reduce it to the normal position, which is convex in its lateral side and concave in its medial side, the traction should be upward to be more effective." "I"

He said that when this fracture occurs, the distal fragments displace anteriorly and outside because the femur is broader at that side.

After the reduction is achieved by applying severe traction, a bandage shouid be applied above the fracture and another one below it if the fracture is in the middle of the fensur.
Fcmur fractures heal within 50 days. The most comrmon complication is deviation at the fracture site.

\section{Patella fractures}

Ibn Sina said: "The patella is rarely fractured, but it is sprained frequently. The fracture is diagnosed by the presence of crepitation which can be palpated or heard. In respect to treatment, the leg should be extended, then the patella be reduced. But if the fracture was comminuted, the fragments should be gathered first then reduced."'s

Al-Räí (who lived before Ibn Sinä) may be the first who pointed to excision of the patella before Brooke (1930). ${ }^{16}$

\section{Leg Fractures}

Ibn Sina stated that fractures of the small bone of a lcg (which is now called the fibula) are better than fractures of the big bone (tibia). If the fracture is in the upper part of the fibula, the deformity is outside and anterior, and walking is possible. If the fracture is in its lower part of the tibia, the deformity is posterior and outside. If the fracture is in both bones, and situation is bad and the deformity may be at any direction.

He said the physician should apply a traction to reduce the fracture in the same method used for forearm fractures.

\section{Talus fractures}

In this chapter, Ibn Sina said the talus is protected against fracture because it is solid and surrounded by structures that guard it. This bone may be dislocated.

Today, this fracture may happen rarely; its diagnosis is difficult unless an X-ray is performed.

\section{Calcaneus fractures}

Ibn Sina said: "Calcaneus fracture is a bad case as its treatment is difficult. It occurs when a person falls down on his feet from a high place.... It may cause severe signs like fever, confusion, tremor, and spasm .... After calcaneus fracture unites walking becomes difficult."

This fracture now is called now parachutists's fracture. The most important complication of this fracture is difficulty it causes in walking. due to the development of osteoarthritis in the talo-calcaneal joint after the union of this fracture.

\section{Toe fractures}

This is the last chapter on fractures. In this clapter. Ibn Sina pointed out that the treatment of toe fractures is like that of the fingers.

\section{Conclusion}

A survey was conducted to find out the most importanl points related to fractures as described by $\mathrm{Ibn}$ Sina in his medical book, "al-Qänun-fit-Tibb."

From this survey we can conclude:

1. Ibn Sina played an important role in keeping the 
medical heritage that developed over thousands of years. His medical book, "al-Qānūn," represents a unique reference document containing medical knowledge in general and traumatology in particular as it accumulated through many civilizations until the age of Ibn Sina.

2. In his way of explanation, Ibn Sina was very close to the way modern medical textbooks follow. At the beginning, he talked about fractures in general. He described their causes, types, forms, methods of treatment, and complications. Then he described the fractures that occur in every bone.

In this respect, one can say that the excellence in its arrangement and comprehensiveness made "al-Qānün" the most widely used medical text book in Islamic and European countries until the 17 th century.

3. Ibn Sina drew attention to the necessity of not splinting the fracture immediately, advising postponing it beyond the fifth day. Today, this is called the theory of delayed splintage; professor George Perkins is considered the pioneer of this theory.

4. Ibn Sina talked about what is called now "Bennet fracture 1882." We know that neither al-Razi before him, nor Ibn-Alquk after him, had described this type of fracture.

In the West, it had been said: "Anyone who wants to be a good doctor must be an Avicennist." A word of truth was written by the European physician De Poure who declared: Medicine was absent until Hippocrates created it, dead un- til Galen revived it, dispersed until Rhases collected it, and deficient until Avicenna completed it.

\section{References}

1. Al-Baba MZ: Some of medical books edited by IbnSina. Aleppo: Institute for the History of Arabic Sciences - Aleppo University, 1984.

2. Ibn Sinä: "Al-Qanūn fit-Tibb. vol. 3, Dar Sader, Lebanon, 1980. 197.

3. Ibn Sinā, vol. 3, p. 197.

4. Ibn $\operatorname{Sin}$, vol. 3 , p. 198.

5. Ibn Sinä, vol.3, p. 199-200.

6. Apley AG, Solomon L: Apley's system of orthopedic fractures. London: Butterworth \& Co., Ltd. 1982, 6th ed., 344.

7. Ibn Sina, vol. 3, p. 210

8. Ibn Sinā, vol.3, p. 213

9. Al-Baba MZ: History and legislation of pharmacy. Damascus: Damascus University, 1986. 132.

10. Ibn Sina, vol. 3, p. 215 .

11. Ibn Sina, vol. 3, p. 215.

12. Rockwood CA, Green DP: Fractures. vol.I London:

H. K. Lewis and Co. Ltd., 1975, 305.

13. Ibn Sinä, vol. 3, p. 215-6.

14. Ibn Sinā, vol.3, p. 216.

15. Ibn Sinä, vol.3, p. 217.

16. Rockwood CA, Green DP: Fractures. vol. 2. London:

HK Lewis and Co. Ltd., 1975, 1153.

17. Ibn Sinä, vol. 3, p. 217. 